\title{
Effect of Tezlien-N7000 soil conditioner on physical and chemical soil properties and barley plant grown in two different soils of Egypt
}

\author{
Hussein Kh. Ahmed ${ }^{1}$ and Hassan A. Fawy ${ }^{2}$
}

\begin{abstract}
A pot experiment was conducted at the greenhouse in El-Nobaria region. The objective of this work was to expose the role of soil conditioner application rate on the properties of sand and loamy sand soils, and on barley yield (Hordium Vulgare) variety Giza 123, as well. In other words, this work aims at throwing the light on the capabilities of soil conditioner so that it might be used as a vehicle for enhancing the physical and chemical properties, especially available moisture and soil fertility status, of a coarse-textured sandy soil and another loamy sand calcareous soil on hope to render these the properties of these soils good enough for plant growth especially under greenhouses or for nursery purposes. The first soil was taken from a farm at the indices $31^{\circ} 17^{\prime} 41^{\prime \prime} \mathrm{N}$ and $30^{\circ} 02^{\prime}$ $60^{\prime \prime} \mathrm{E}$, while the second was taken at 30' $21^{\prime} 29^{\prime \prime} \mathrm{N}$ and $30^{\circ}$ 27' 39" E. The former soil represents sandy soil, while the other loamy sand calcareous soil. In both locations, soil samples were collected from the $0-30 \mathrm{~cm}$ soil layer. Soil conditioner (Tezlien-N 7000) was thoroughly mixed with the soil at the rates of $0.125,0.250$, and $0.500 \mathrm{Kg} /$ Ton by weight of the soil in the pots. Results reveal that, soil conditioner application lowered soil $\mathbf{p H}$ and increased soil EC, CEC, OM, and available NPK of both soils. It also increased of the emergence, chlorophyll $a$ and $b$ and yield parameter of barley in both soils. The soil conditioner was more profound in the sandy than in the sandy loam soil.

It can be concluded that increasing the rate of conditioner application to $0.25 \mathrm{Kg}$ /Ton was the best for bringing about the best soil moisture characteristics; hence the best seed emergence and plant growth. This rate could also provide the most appropriate available water and soil fertility level then could produce the best grain and straw yields of barley plants.
\end{abstract}

\section{INTRODUCTION}

Sandy soil is known of its narrow range of available moisture. By the time the loamy sand calcareous soil is known of abrupt change in its consistency when it becomes dry leading to the injury of plant roots. In this respect, Wallace and Wallace (1986) stressed the favorable effect of hydro-gels on soil physical properties, particularly percolation and infiltration rates, mainly through affecting particle size distribution of the soil. Also, Woodhouse and Johnson (1991) found that incorporating hydro-gels into soil structure aided in

\footnotetext{
${ }^{1}$ Soils and Water Dept., Faculty of Agric., Al-Azhar Univ.

2 Soil Fertility and Microbiology Dept., Desert Research

Center (DRC), Cairo

Received August 30, 2007, Accepted September 30, 2007
}

germination of Hordeum vulgare (barley).El Sayed et al. (1991) observed that the addition of hydrogels to soil increased pigments, photosynthesis activity, and protein contents in plants. Trout et al (1995) reported that polyacrylamide (PAM) increased mean infiltration by $30 \%$. In the same line, incorporating hydro-gels into the surface soil increased the infiltration capacity and the overall water availability (Zhang and Miller 1996). The effectiveness of hydrophilic polymers in enhancing soil water retention depends on their formulation as well as on soil type (Choudhary et al., 1995). For example, PAM decreased the bulk density of sandy soil from 1.616 to $1.585 \mathrm{~g} / \mathrm{cm} 3$ and that of sandy clay soil from 1.331 to $1.203 \mathrm{~g} / \mathrm{cm} 3$ at rates of up to $0.4 \%$ hydro-gel (Al-Harbi et al. 1999). Geesing and Schmidhalter (2004) reported that water-holding capacity of the soils increased when the soil was amended with a polymer at a rate $>3 \mathrm{~g} / \mathrm{L}$. Also, Sivapalan (2004) stated that water retention by a sandy soil against a $0.01 \mathrm{MPa}$ pressure $(0.1$ bar) increased by 23 and $95 \%$ by adding 0.03 and $0.07 \%$ of the polymer amendment, respectively. In addition, all retained moisture was completely available to soybean plants, i.e. enhanced water use efficiency.

Regarding soil fertility, Polyakova (1976) incorporated hydro-gels into the soil at the rates of 100 , 150 , and $200 \mathrm{~kg} / \mathrm{ha}$ and obtained increases of 27 to $140 \%$ in the wheat production over the non-treated control. Flannery and Busscher (1982) stated that hydro-gels reduced fertilizer (NPK) leaching, which was referred to the interaction of the fertilizer with the polymer. FinchSavage and Cox (1982) added sodium phosphate to a hydro-gel and noticed a significant increase in seedling growth of lettuce and onion. In addition, Wang (1989) used hydro-gels in the growth medium to increase levels of nitrogen and potassium in plants. Wallace and Wallace (1990) stated that hydrophilic polymers enhanced plant growth by making the impregnated nutrients more available to roots. For example, impregnated phosphorus increased seedling growth of chili peppers. Abraham and Pillai (1995) found that urea-coated with hydrophilic polymers significantly reduced the amount of ammonium leaching. In addition, Geesing and Schmidhalter (2004) reported that grain N 
content and yield increased with high polymer rates.

Mortvedt et al. (1993) mixed polymers with soluble fertilizers of micronutrients such as iron, copper, manganese, or zinc and observed greater uptake efficiency. Also, Mikkelsen (1995) revealed that hydrophilic polymer with soluble $\mathrm{Mn}$ fertilizers enhanced plant recovery. The objective of this work was to expose the role of soil conditioner application rate on the properties of sand and loamy sand soils, and on barley yield, as well.

\section{MATERIALS AND METHODS}

A pot experiment was conducted at the greenhouse in El-Nobaria region. Two soils were used the first soil was taken from a farm owned by Khamees Ali Ahmed in El Maamora region at Alexandria, the indices assessed by the GPS as $31^{\circ} 17^{\prime} 41^{\prime \prime} \mathrm{N}$ and $30^{\circ} 02^{\prime} 60^{\prime \prime} \mathrm{E}$, which is very close to the El Maamora land Reform Station in Alexandria. This soil was sandy. The second soil was taken from Wadi-El-Natroun, very close to prison 2 at the indices of $30^{\circ} 21^{\prime} 29^{\prime \prime} \mathrm{N}$ and $30^{\circ} 27^{\prime} 39^{\prime \prime} \mathrm{E}$ and the land lord is called Mohammed Bieh El-Zabit. The soil is clearly calcareous based on the bare eye judgment. In both locations, soil samples were collected from the 0 $30 \mathrm{~cm}$ soil layer.

Twenty-kg of each soil sample was put in a plastic pot that was $33 \mathrm{~cm}$ high and $23.2 \mathrm{~cm}$ wide in mean diameter. Soil conditioner was thoroughly mixed with the soil at the rates of $0.125,0.250$, and $0.5 \mathrm{Kg} / \mathrm{Ton}$ soil by weight of the soil before sowing. The used polymer was Tezlien-N 7000, which is formulated as anionic surfactant granules. It is hydrophilic, yellowish white, with a density of $0.75 \mathrm{gm} / \mathrm{cm}^{3}, \mathrm{pH} 5.6$, EC $0.35 \mathrm{dS} / \mathrm{m}$, Mw 40,000-180,000.Micich et al (1986).

Phosphorus, as super phosphate, was added to each pot $(8 \mathrm{~g} / \mathrm{pot}$ or $60 \mathrm{~kg} / \mathrm{fed})$ and thoroughly mixed with the soil. Soil in each pot was irrigated with enough water to stay wet enough to sustain a satisfactory grain germination. Then, the pots were to be watered along the plants' life span by applying the lost amount of irrigation water up to the field capacity of each studied soil. Barley (Hordium Vulgare) variety Giza 123 was the best grain crop for the experimental areas. Twentyfive barley grains were sown into the wet topsoil in each pot. Emergence vigor was determined after 5, 10, and 15 days from sowing, i.e. up to full possible emergence. So, the number of germinated plants was recorded after these periods of time. Plants were left until the end of their life span, at which grain, straw, and biological yields were recorded.

The total amount of applied $\mathrm{N}$ was $10 \mathrm{~g}$ of $\left(\mathrm{NH}_{4}\right)_{2}$ $\mathrm{SO}_{4}$, while that of $\mathrm{K}$ was $4 \mathrm{~g} \mathrm{~K}_{2} \mathrm{SO}_{4}$ per pot. These amounts were recommended for wheat and barley to reach into yield goal and equivalent to 100 and $100 \mathrm{~kg} / \mathrm{fed}$ of $\mathrm{N}$ and $\mathrm{K}_{2} \mathrm{O}$, respectively. Nitrogen and potassium fertilizers were split into three equal doses that were applied after 15, 30 and 75 days from sowing.

The application of micronutrients was avoided to give the soil conditioner the chance to exhibit its role in rendering available to plant absorption the native content of these nutrients in the soil and also the amount that may possibly be applied with the used fertilizers and/or may be accompanying the conditioner itself.

Soil samples were exposed to 0.1 bar (field capacity) and 15.0 bar (wilting percentage) by the pressure cocker and pressure membrane apparatus (Richards, 1954). The available water was then calculated as the difference between soil moisture content at those two soil moisture tensions. Soil bulk density was determined using the core samples from all experimental pots according to Klute (1986).

During the booting stage of barley plants, leaf contents of chlorophyll $\mathrm{a}$ and $\mathrm{b}$, and carotene were estimated. At harvest, soil pH, EC, CEC, OM, available $\mathrm{N}, \mathrm{P}, \mathrm{K}, \mathrm{Fe}, \mathrm{Mn}, \mathrm{Zn}$, and $\mathrm{Cu}$ were measured to trace the effect of the applied rates of soil conditioner on these properties. Field capacity, wilting percentage, available moisture range, and bulk density of the two studied soils were also measured. Concentrations of $\mathrm{N}, \mathrm{P}, \mathrm{K}, \mathrm{Fe}, \mathrm{Mn}$, $\mathrm{Zn}$, and $\mathrm{Cu}$ were estimated in plants during shooting that was denoted in this work as the first stage, booting (second stage), and harvest. Finally, barley grain and straw yields were recorded. All collected data were subjected to statistical analysis and treatments' means were differentiated.

Collected samples were brought to the greenhouse in El-Nobaria region. These samples were air-dried, ground, passed through a 2-mm sieve and preserved in plastic containers for future analyses. Soil physical and chemical properties of the experimental site were measured according to Page et al (1982). Soil texture was achieved by dry sieving analysis. In soil paste extract, soil $\mathrm{pH}, \mathrm{EC}$, and water soluble cations and anions were measured. Soluble $\mathrm{Na}^{+}$and $\mathrm{K}^{+}$were measured flame-photometrically, $\mathrm{Ca}^{++}$and $\mathrm{Mg}^{++}$ titrimetrically using versinate, $\mathrm{HCO}_{3}^{-}$titrimetrically using dilute $\mathrm{HCl}$, and $\mathrm{Cl}^{-}$titrimetrically using silver nitrate. Sulfate was determined turbidimetrically. Calcium carbonate content of the soil was achieved using a calcimeter. Available $\mathrm{N}$ was measured according to Onken and Sunderman (1977). Available P content was achieved according to Olsen et al (1954), while available $\mathrm{K}$ was measured using ammonium acetate solution according to Page et al. (1982). Soil available micronutrients were extracted by DTPA and measured by an atomic absorption spectrophotometer PYE 
Table 1. Soil physical and chemical properties of the studied soils.

\begin{tabular}{|c|c|c|c|c|c|c|c|c|}
\hline Locations & $\begin{array}{c}(\mathbf{p H}) \\
1: 1\end{array}$ & O.M & \multicolumn{3}{|c|}{$\%$} & Clay & $\begin{array}{c}\text { Texture } \\
\text { class }\end{array}$ & $\begin{array}{c}\text { CEC } \\
\mathrm{me} / 100 \mathrm{~g}\end{array}$ \\
\hline El-Maamora & 7.3 & 0.11 & 61.4 & 25.6 & 5.9 & 7.1 & $\mathrm{~S}$ & 1.5 \\
\hline \multirow[t]{3}{*}{ Wadi El-Natroun } & 7.8 & 0.25 & 5.0 & 63.2 & 12.8 & 19.0 & SL & 18.0 \\
\hline & $\mathrm{EC} \mathrm{dS} / \mathrm{m}$ & $\mathrm{Ca}^{+2}$ & $\mathrm{Mg}^{+2}$ & $\mathrm{Na}^{+}$ & $\mathrm{K}^{+}$ & $\mathrm{HCO}_{3}^{-1}$ & $\mathrm{CL}^{-1}$ & $\mathrm{SO}_{4}^{-2}$ \\
\hline & $1: 1$ & \multicolumn{7}{|c|}{ Water soluble ions $\mathrm{me} / \mathrm{L}$} \\
\hline El-Maamora & 0.25 & 0.15 & 0.01 & 0.05 & 0.04 & 0.15 & 0.1 & 0.02 \\
\hline \multirow[t]{2}{*}{ Wadi El-Natroun } & 1.6 & 0.36 & 0.10 & 0.96 & 0.17 & 0.68 & 0.4 & 0.48 \\
\hline & $\mathrm{CaCO}_{3}$ & F.C. & $\begin{array}{l}\text { WP } \\
\%\end{array}$ & \multicolumn{2}{|c|}{ Av. M } & \multicolumn{3}{|c|}{$\begin{array}{l}\text { Bulk density }(\rho \mathrm{b}) \\
\mathrm{g} / \mathrm{cm} 3\end{array}$} \\
\hline El-Maamora & 2.9 & 12.3 & 2.4 & \multicolumn{2}{|c|}{9.9} & \multicolumn{3}{|c|}{1.25} \\
\hline \multirow[t]{3}{*}{ Wadi El-Natroun } & 28.3 & 17.2 & 4.9 & & & & 1.47 & \\
\hline & & \multicolumn{7}{|c|}{ Available nutrients(ppm) } \\
\hline & $\mathrm{N}$ & $\mathrm{P}$ & $\mathrm{K}$ & $\mathrm{Fe}$ & $\mathrm{Mn}$ & $\mathrm{Zn}$ & \multicolumn{2}{|c|}{$\mathrm{Cu}$} \\
\hline El-Maamora & 9.8 & 2.5 & 50 & 1.18 & 0.98 & 0.41 & \multicolumn{2}{|c|}{0.17} \\
\hline Wadi El-Natroun & 30.8 & 3.6 & 101 & 2.06 & 1.64 & 0.61 & \multicolumn{2}{|c|}{0.33} \\
\hline
\end{tabular}

UNICAM 1900 (Lindsay and Norvell, 1978). Obtained values of physical and chemical analyses are depicted in table (1). Soil organic matter was determined according to the methods described by Black et al. (1982), while CEC was determined using the sodium saturation method for the sandy soil and for calcareous soil (loamy sand) it was determined according to modified Hissink's method (Gohar, 1954).

Plant samples were collected at three growth stages. The first was taken three weeks after emergence as whole plants (after one week of $\mathrm{N}$ and $\mathrm{K}$ addition). The second was before heading stage (during the booting stage), while the third sample was at harvest time. These samples were oven-dried at $60^{\circ} \mathrm{C}$ to avoid any loss of nitrogen compounds from plant samples, milled, and preserved in plastic bags for future analyses. Plant samples were digested according to Parkinson and Allen (1975) and Wolf (1982). They used a mixture of $\mathrm{H}_{2} \mathrm{SO}_{4}$ and $\mathrm{H}_{2} \mathrm{O}_{2}$ to digest plant dry matter and determine $\mathrm{N}, \mathrm{P}$, $\mathrm{K}, \mathrm{Fe}, \mathrm{Mn}, \mathrm{Zn}$, and $\mathrm{Cu}$. In digested samples, nutrients' concentrations were determined, and then the nutrient content in grains and straw was calculated.

During the booting stage of barley plants, chlorophyll $\mathrm{a}$ and $\mathrm{b}$ and carotene were determined as described by Wettstein (1957). At harvest, NPK and some micro-nutrients were determined in the produced dry matter (grain and straw) per treatment. These elements were determined as mentioned above.

The applied treatments resembled three conditioner rates, as well as a control treatment. These four treatments were applied to the two adopted soils in this study. Each treatment was allowed six pots and the treatments were arranged in completely randomized statistical design (Gomez and Gomez, 1984).
Treatments' means were differentiated using the least significant range (LSR) according to Duncan (1955).

\section{RESULTS AND DISCUSSION}

Table (2) shows that increasing the rate of soil conditioner application significantly lowered soil $\mathrm{pH}$ in both soils under study. This reveals that the conditioner itself is capable of contributing to rising hydrogen concentration. It also increased soil EC, CEC, OM, and available NPK of both soils.

Table 2. Effect of soil conditioner level on some chemical properties of the two studied soils.

These results were taking after fertilizer application for both soils. The soil conditioner accumulated the elements and bonded with its in soil, this make to high for EC in soils, plants uptake the elements from soils during growth it self and leaching by irrigation process. This agrees with the findings of Flannery and Busscher (1982). They stated that hydro-gels reduced fertilizer (NPK) leaching owing to the interaction of the fertilizer with the polymer. This can be attributed to the contribution of the soil conditioner particles to these soil properties either by its natural properties themselves or by other secondary interactions with soil components.

This coincides with the findings of Wang (1989), who stated that hydro-gels increased the levels of nitrogen and potassium in plant tissue. Also, Abraham and Pillai (1995) found that urea-coated with hydrophilic polymers significantly reduced the amount of ammonium leaching. The influence of soil conditioner rate of application was steadily linear in sand soil than in finer texture soil; sandy loam, especially regarding $\mathrm{N}, \mathrm{P}$, and $\mathrm{K}$.

From another viewpoint, increasing the dose of 
Table 2. Effect of soil conditioner level on some chemical properties of the two studied soils.

\begin{tabular}{|c|c|c|c|c|c|c|c|}
\hline \multirow{2}{*}{ Conditioner Kg/Ton } & \multirow{2}{*}{ pH1:1 } & \multirow{2}{*}{ EC dS/m 1:1 } & \multirow{2}{*}{$\begin{array}{c}\text { CEC } \\
\text { me/100g soil }\end{array}$} & \multirow[t]{2}{*}{ OM\% } & \multicolumn{3}{|c|}{ Available (ppm) } \\
\hline & & & & & $\mathbf{N}$ & $\mathbf{P}$ & K \\
\hline \multicolumn{8}{|c|}{ Sand soil } \\
\hline Control & $7.30 \mathrm{a}^{*}$ & $0.25 \mathrm{~d}$ & $1.50 \mathrm{~d}$ & $0.11 \mathrm{~b}$ & $8.2 \mathrm{~d}$ & $2.14 \mathrm{~d}$ & $42 \mathrm{~d}$ \\
\hline 0.125 & $7.25 \mathrm{a}$ & $0.50 \mathrm{c}$ & $1.70 \mathrm{c}$ & $0.15 \mathrm{~b}$ & $16.1 \mathrm{c}$ & $4.50 \mathrm{c}$ & $58 \mathrm{c}$ \\
\hline 0.250 & $7.10 \mathrm{~b}$ & $0.75 b$ & $1.83 \mathrm{~b}$ & $0.20 \mathrm{a}$ & $23.1 \mathrm{~b}$ & $6.30 \mathrm{~b}$ & $76 \mathrm{~b}$ \\
\hline 0.500 & $7.01 \mathrm{~b}$ & $1.00 \mathrm{a}$ & $2.40 \mathrm{a}$ & $0.28 \mathrm{a}$ & $28.3 \mathrm{a}$ & $7.10 \mathrm{a}$ & $85 \mathrm{a}$ \\
\hline \multicolumn{8}{|c|}{ Sandy loam soil } \\
\hline Control & $7.80 \mathrm{a}$ & $1.60 \mathrm{~d}$ & $14.00 \mathrm{~d}$ & $0.25 \mathrm{c}$ & $26.1 \mathrm{~d}$ & $3.16 \mathrm{c}$ & $83 \mathrm{~d}$ \\
\hline 0.125 & $7.75 \mathrm{a}$ & $1.81 \mathrm{c}$ & $17.61 \mathrm{c}$ & $0.38 \mathrm{~b}$ & $35.5 \mathrm{c}$ & $6.50 \mathrm{~b}$ & $97 \mathrm{c}$ \\
\hline 0.250 & $7.50 \mathrm{~b}$ & $1.97 \mathrm{~b}$ & $19.90 \mathrm{~b}$ & $0.59 \mathrm{a}$ & $49.1 \mathrm{~b}$ & $7.7 \mathrm{a}$ & $129 \mathrm{~b}$ \\
\hline 0.500 & $7.30 \mathrm{c}$ & $2.10 \mathrm{a}$ & $21.30 \mathrm{a}$ & $0.63 \mathrm{a}$ & $53.6 \mathrm{a}$ & $8.1 \mathrm{a}$ & $135 \mathrm{a}$ \\
\hline
\end{tabular}

*In each column (box) for each soil, every two values sharing an alphabet are not significantly different at $5 \%$ level of significance.

Table 3. Effect of soil conditioner level on available water and bulk density of the studied soils.

\begin{tabular}{|c|c|c|c|c|}
\hline \multirow{2}{*}{ Conditioner Kg/Ton } & FC & WP & Available water & Bulk density ( $\rho b)$ \\
\hline & \multicolumn{3}{|r|}{ 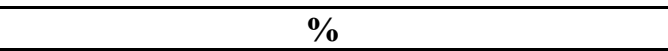 } & $\mathrm{g} / \mathrm{cm}^{3}$ \\
\hline \multicolumn{5}{|c|}{ Sand soil } \\
\hline Control & $12.3 \mathrm{~d}^{*}$ & $3.4 \mathrm{c}$ & $8.9 \mathrm{c}$ & $1.75 \mathrm{a}$ \\
\hline 0.125 & $14.6 \mathrm{c}$ & $4.2 \mathrm{~b}$ & $10.4 \mathrm{c}$ & $1.67 \mathrm{~b}$ \\
\hline 0.250 & $17.8 \mathrm{~b}$ & $5.5 \mathrm{a}$ & $12.3 \mathrm{~b}$ & $1.50 \mathrm{c}$ \\
\hline 0.500 & $20.1 \mathrm{a}$ & $5.8 \mathrm{a}$ & $14.3 \mathrm{a}$ & $1.47 \mathrm{c}$ \\
\hline \multicolumn{5}{|c|}{ Sandy loam soil } \\
\hline Control & $17.2 \mathrm{~d}$ & $4.9 \mathrm{c}$ & $12.3 \mathrm{~b}$ & $1.45 \mathrm{a}$ \\
\hline 0.125 & $18.3 \mathrm{c}$ & $5.3 \mathrm{bc}$ & $13.0 \mathrm{~b}$ & $1.39 \mathrm{ab}$ \\
\hline 0.250 & $19.5 \mathrm{~b}$ & $5.6 \mathrm{~b}$ & $13.9 \mathrm{a}$ & $1.30 \mathrm{bc}$ \\
\hline 0.500 & $22.3 \mathrm{a}$ & $6.2 \mathrm{a}$ & $16.1 \mathrm{a}$ & $1.25 \mathrm{c}$ \\
\hline
\end{tabular}

*In each column (box) for each soil, every two values sharing an alphabet are not significantly different at 5\% level of significance.

conditioner application significantly widened the available range of soil moisture (Table 3 ) by greatly increasing $g$ field capacity and slightly increasing the wilting percentage. In so doing, soil conditioner enhances soil moisture characteristics for the sake of plant irrigation. This is in agreement with Zhang and Miller (1996). They stated that incorporating hydro-gels into the surface soil increased the overall water availability.

Regarding micro-nutrients, table (4) reveals that the concentrations of such nutrients were very low in the two studied soils. But still, a trend can be identified. The same table (4) shows that increasing the dose of conditioner application could approximately steadily increase their concentrations in the soil extract of the sand soil, whereas the greater two rates did not significantly differ in this regard in the sandy loam soil. In other words, the effect of the soil conditioner was more profound in the sandy than in the sandy loam soil. our finding may simulate the findings of Mortvedt et al. (1993), who mixed polymers with soluble fertilizers of micronutrients and observed greater uptake efficiency of micronutrients by plants. This effect was steadier in the sand soil than in the finer sandy loam soil. concentration.

Data in table (5) reveal that increased dose of conditioner had a remarkable effect on the emergence of barley grains in both soils, especially the sandy one. This goes well with the finding of Woodhouse and Johnson (1991), who found that hydro-gels led to a better germination of barley. So, the higher the rate of the conditioner the greater the moisture around the grains (Wallace and Wallace, 1990).

In addition, increasing the rate of soil conditioner application significantly scored highest compared with the lower rates on bringing about chlorophyll $a$ and $b$ as well as on carotene in barley leaves in both soils under study (Table 6). So, the conditioner rendered more moisture as well as more nutrients available to barley roots, hence there was a more profound build-up of chlorophyll a, b, and carotene in plant leaves. This agrees with the findings of El Sayed et al. (1991), who 
Table 4. Effect of soil conditioner level on the availability of micro-nutrients in the studied soils.

\begin{tabular}{|c|c|c|c|c|}
\hline \multirow{2}{*}{ Conditioner $\mathrm{Kg} / \mathrm{Ton}$} & \multicolumn{4}{|c|}{ Available (ppm) } \\
\hline & $\mathbf{F e}$ & Mn & $\mathbf{Z n}$ & $\mathbf{C u}$ \\
\hline \multicolumn{5}{|c|}{ Sand soil } \\
\hline Control & $1.05 \mathrm{~d}$ & $0.88 \mathrm{~d}$ & $0.38 \mathrm{~d}$ & $0.16 \mathrm{~d}$ \\
\hline 0.125 & $1.48 \mathrm{c}$ & $1.05 \mathrm{c}$ & $0.61 \mathrm{c}$ & $0.27 \mathrm{c}$ \\
\hline 0.250 & $1.84 \mathrm{~b}$ & $1.19 \mathrm{~b}$ & $0.74 \mathrm{~b}$ & $0.34 \mathrm{~b}$ \\
\hline 0.500 & $2.32 \mathrm{a}$ & $1.27 \mathrm{a}$ & $0.82 \mathrm{a}$ & $0.46 \mathrm{a}$ \\
\hline \multicolumn{5}{|c|}{ Sandy loam soil } \\
\hline Control & $1.81 \mathrm{~d}$ & $1.49 \mathrm{~d}$ & $0.56 \mathrm{~d}$ & $0.32 \mathrm{~d}$ \\
\hline 0.125 & $2.46 \mathrm{c}$ & $1.76 \mathrm{c}$ & $0.67 \mathrm{c}$ & $0.41 \mathrm{c}$ \\
\hline 0.250 & $2.69 \mathrm{~b}$ & $2.07 \mathrm{~b}$ & $0.85 \mathrm{~b}$ & $0.51 \mathrm{~b}$ \\
\hline 0.500 & $2.88 \mathrm{a}$ & $2.36 \mathrm{a}$ & $0.98 \mathrm{a}$ & $0.63 \mathrm{a}$ \\
\hline
\end{tabular}

* In each column (box) for each soil, every two values sharing an alphabet are not significantly different at $5 \%$ level of significance.

Table 5. Effect of soil conditioner level on average seed emergence of barley under the two studied soils.

\begin{tabular}{|c|c|c|c|}
\hline \multirow{2}{*}{ Conditioner Kg/Ton } & \multicolumn{3}{|c|}{ Seed emergence of barley \% } \\
\hline & 5 days & 10 days & 15 days \\
\hline \multicolumn{4}{|c|}{ Sand soil } \\
\hline Control & $13 d^{*}$ & $29 \mathrm{~d}$ & $58 \mathrm{~d}$ \\
\hline 0.125 & $27 \mathrm{c}$ & $72 \mathrm{c}$ & $82 \mathrm{c}$ \\
\hline 0.250 & $39 b$ & $77 b$ & $87 b$ \\
\hline 0.500 & $44 \mathrm{a}$ & $82 \mathrm{a}$ & $96 a$ \\
\hline \multicolumn{4}{|c|}{ Sandy loam soil } \\
\hline Control & $33.6 \mathrm{~d}$ & $62 \mathrm{c}$ & $75 d$ \\
\hline 0.125 & $52.4 \mathrm{c}$ & $78 b$ & $84 \mathrm{c}$ \\
\hline 0.250 & $61.2 \mathrm{~b}$ & $85 \mathrm{a}$ & $94 b$ \\
\hline 0.500 & $65.6 \mathrm{a}$ & $88 \mathrm{a}$ & $99 \mathrm{a}$ \\
\hline
\end{tabular}

* In each column (box) for each soil, every two values sharing an alphabet are not significantly different at 5\% level of significance.

Table 6. Effect of soil conditioner level on chlorophyll and carotene contents in barley plant leaves in sand and sandy loam soils.

\begin{tabular}{|c|c|c|c|c|c|c|}
\hline \multirow{4}{*}{ Conditioner Kg/Ton } & \multicolumn{3}{|c|}{ Sand soil } & \multicolumn{3}{|c|}{ Sandy loam soil } \\
\hline & \multicolumn{2}{|c|}{ Chlorophyll } & \multirow{2}{*}{ Carotenoids } & \multicolumn{2}{|c|}{ Chlorophyll } & \multirow{2}{*}{ Carotenoids } \\
\hline & $\mathbf{a}$ & b & & $\mathbf{a}$ & $\mathbf{b}$ & \\
\hline & \multicolumn{6}{|c|}{ (mg/g fresh wt.) } \\
\hline Control & $0.34 b^{*}$ & $0.25 \mathrm{~b}$ & $0.15 \mathrm{c}$ & $0.42 \mathrm{~d}$ & $0.32 \mathrm{~d}$ & $0.23 \mathrm{c}$ \\
\hline 0.125 & $0.44 \mathrm{~b}$ & $0.33 \mathrm{~b}$ & $0.23 \mathrm{bc}$ & $0.65 \mathrm{c}$ & $0.46 \mathrm{c}$ & $0.33 \mathrm{c}$ \\
\hline 0.250 & $0.64 \mathrm{a}$ & $0.50 \mathrm{a}$ & $0.33 \mathrm{ab}$ & $0.95 \mathrm{~b}$ & $0.73 \mathrm{~b}$ & $0.46 \mathrm{~b}$ \\
\hline 0.500 & $0.77 \mathrm{a}$ & $0.63 \mathrm{a}$ & $0.46 \mathrm{a}$ & $1.23 \mathrm{a}$ & $0.93 \mathrm{a}$ & $0.64 \mathrm{a}$ \\
\hline
\end{tabular}

* In each column (box) for each soil, every two values sharing an alphabet are not significantly different at $5 \%$ level of significance.

observed that additions of hydrogels to soil increased pigments, photosynthesis activity, and protein contents in plants.

From the above mentioned, it can be concluded that applying soil conditioner was beneficial in sand soil, whereas in fine-textured soil the application rate may be diminished to lower rates since the fine texture may compensate for the excess of the conditioner.

Data in table (7) reveal that increasing the application rate of soil conditioner up to $0.25 \mathrm{Kg} / \mathrm{Ton}$ could significantly bring highest significant concentrations of $\mathrm{N}, \mathrm{P}$, and $\mathrm{K}$ in barley leaves at all growth stages in both studied soils. Increasing the application rate to $0.50 \mathrm{Kg} / \mathrm{T}$ on could not significant increase in the concentrations of these nutrients. It seems that the rate of soil conditioner application should limited to $0.25 \mathrm{Kg} /$ Ton owing to its high expenses, besides doing the required benefit of enhancing soil physical and nutrient status. This goes with Flannery and 
Table 7. Effect of soil conditioner level on the concentration of macronutrients in barley at different growth stages.

\begin{tabular}{|c|c|c|c|c|c|c|c|c|}
\hline \multirow{3}{*}{ Conditioner Kg/Ton } & \multicolumn{4}{|c|}{ Sand soil } & \multicolumn{4}{|c|}{ Sandy loam soil } \\
\hline & \multirow{2}{*}{$\begin{array}{c}\text { Stage } \\
1\end{array}$} & \multirow{2}{*}{$\frac{\text { Stage }}{2}$} & \multicolumn{2}{|c|}{ Harvest stage } & \multirow{2}{*}{$\begin{array}{c}\text { Stage } \\
1\end{array}$} & \multirow{2}{*}{$\frac{\text { Stage }}{2}$} & \multicolumn{2}{|c|}{ Harvest stage } \\
\hline & & & Grain & Straw & & & Grain & Straw \\
\hline \multicolumn{9}{|c|}{ Nitrogen $(\%)$} \\
\hline Control & $1.59 \mathrm{c} *$ & $0.91 \mathrm{c}$ & $0.23 \mathrm{c}$ & $0.72 \mathrm{~d}$ & $2.90 \mathrm{~d}$ & $2.04 \mathrm{~d}$ & $0.45 \mathrm{~d}$ & $1.35 \mathrm{~d}$ \\
\hline 0.125 & $3.25 \mathrm{~b}$ & $2.47 \mathrm{~b}$ & $0.47 \mathrm{~b}$ & $1.30 \mathrm{c}$ & $4.09 \mathrm{c}$ & $2.89 \mathrm{c}$ & $0.60 \mathrm{c}$ & $1.74 \mathrm{c}$ \\
\hline 0.250 & $4.32 \mathrm{a}$ & $3.36 \mathrm{a}$ & $0.58 \mathrm{a}$ & $1.68 \mathrm{~b}$ & $5.82 \mathrm{~b}$ & $4.12 \mathrm{~b}$ & $0.86 \mathrm{~b}$ & $2.08 \mathrm{~b}$ \\
\hline 0.500 & $4.43 \mathrm{a}$ & $3.50 \mathrm{a}$ & $0.64 \mathrm{a}$ & $1.82 \mathrm{a}$ & $6.76 \mathrm{a}$ & $5.28 \mathrm{a}$ & $1.04 \mathrm{a}$ & $2.72 \mathrm{a}$ \\
\hline \multicolumn{9}{|c|}{ Phosphorus (\%) } \\
\hline Control & $0.17 \mathrm{c}$ & $0.13 \mathrm{c}$ & $0.04 \mathrm{~b}$ & $0.11 \mathrm{~b}$ & $0.30 \mathrm{~d}$ & $0.21 \mathrm{~b}$ & $0.08 \mathrm{~b}$ & $0.18 \mathrm{c}$ \\
\hline 0.125 & $0.46 \mathrm{~b}$ & $0.36 \mathrm{~b}$ & $0.08 \mathrm{ab}$ & $0.23 \mathrm{a}$ & $0.96 \mathrm{c}$ & $0.60 \mathrm{a}$ & $0.20 \mathrm{a}$ & $0.39 \mathrm{~b}$ \\
\hline 0.250 & $0.65 \mathrm{a}$ & $0.44 \mathrm{a}$ & $0.13 \mathrm{a}$ & $0.29 \mathrm{a}$ & $1.24 \mathrm{~b}$ & $0.66 \mathrm{a}$ & $0.23 \mathrm{a}$ & $0.46 a b$ \\
\hline 0.500 & $0.72 \mathrm{a}$ & $0.47 \mathrm{a}$ & $0.14 \mathrm{a}$ & $0.31 \mathrm{a}$ & $1.40 \mathrm{a}$ & $0.65 \mathrm{a}$ & $0.26 \mathrm{a}$ & $0.48 \mathrm{a}$ \\
\hline \multicolumn{9}{|c|}{ Potassium (\%) } \\
\hline Control & $0.62 \mathrm{c}$ & $0.48 \mathrm{c}$ & $0.35 \mathrm{c}$ & $0.12 \mathrm{c}$ & $1.22 \mathrm{~d}$ & $0.97 \mathrm{c}$ & $0.56 \mathrm{c}$ & $0.22 \mathrm{c}$ \\
\hline 0.125 & $2.65 \mathrm{~b}$ & $1.97 \mathrm{~b}$ & $0.90 \mathrm{~b}$ & $0.26 \mathrm{bc}$ & $3.77 \mathrm{c}$ & $2.59 \mathrm{~b}$ & $1.82 \mathrm{~b}$ & $0.38 \mathrm{~b}$ \\
\hline 0.250 & $3.21 \mathrm{a}$ & $2.35 \mathrm{a}$ & $1.16 \mathrm{a}$ & $0.35 \mathrm{ab}$ & $5.88 \mathrm{~b}$ & $4.39 \mathrm{a}$ & $2.94 \mathrm{a}$ & $0.66 \mathrm{a}$ \\
\hline 0.500 & $3.34 \mathrm{a}$ & $2.41 \mathrm{a}$ & $1.22 \mathrm{a}$ & $0.38 \mathrm{a}$ & $6.08 \mathrm{a}$ & $4.51 \mathrm{a}$ & $3.09 \mathrm{a}$ & $0.68 \mathrm{a}$ \\
\hline
\end{tabular}

*In each column (box) for each soil, every two values sharing an alphabet are not significantly different at $5 \%$ level of significance.

Table 8. Effect of soil conditioner level on the concentration of micronutrients in barley at different growth stages.

\begin{tabular}{|c|c|c|c|c|c|c|c|c|}
\hline \multirow{3}{*}{ Conditioner Kg/Ton } & \multicolumn{4}{|c|}{ Sand soil } & \multicolumn{4}{|c|}{ Sandy loam soil } \\
\hline & \multirow{2}{*}{$\begin{array}{c}\text { Stage } \\
1\end{array}$} & \multirow{2}{*}{$\begin{array}{c}\text { Stage } \\
2\end{array}$} & \multicolumn{2}{|c|}{ Harvest stage } & \multirow{2}{*}{$\begin{array}{c}\text { Stage } \\
1\end{array}$} & \multirow{2}{*}{$\begin{array}{c}\text { Stage } \\
2\end{array}$} & \multicolumn{2}{|c|}{ Harvest stage } \\
\hline & & & Grain & Straw & & & Grain & Straw \\
\hline \multicolumn{9}{|c|}{ Iron (ppm) } \\
\hline Control & $68 \mathrm{c} *$ & $42 \mathrm{~d}$ & $45 \mathrm{~d}$ & $40 \mathrm{~d}$ & $103 \mathrm{c}$ & $75 \mathrm{~d}$ & $73 d$ & $68 \mathrm{c}$ \\
\hline 0.125 & $157 \mathrm{~b}$ & $101 \mathrm{c}$ & $81 \mathrm{c}$ & $73 \mathrm{c}$ & $256 \mathrm{~b}$ & $177 \mathrm{c}$ & $144 \mathrm{c}$ & $137 \mathrm{~b}$ \\
\hline 0.250 & 217 a & $140 \mathrm{~b}$ & $104 \mathrm{~b}$ & $99 \mathrm{~b}$ & $317 \mathrm{a}$ & $207 \mathrm{~b}$ & $181 \mathrm{~b}$ & $170 \mathrm{a}$ \\
\hline 0.500 & $237 \mathrm{a}$ & $187 \mathrm{a}$ & $123 \mathrm{a}$ & $117 \mathrm{a}$ & $330 \mathrm{a}$ & $236 \mathrm{a}$ & $195 \mathrm{a}$ & $182 \mathrm{a}$ \\
\hline \multicolumn{9}{|c|}{ Manganese (ppm) } \\
\hline Control & $20.6 \mathrm{~d}$ & $16.2 \mathrm{~d}$ & $15 \mathrm{c}$ & $12.8 \mathrm{c}$ & $36 \mathrm{c}$ & $27 \mathrm{c}$ & $25 \mathrm{c}$ & $19 \mathrm{c}$ \\
\hline 0.125 & $47.2 \mathrm{c}$ & $36.3 \mathrm{c}$ & $25 \mathrm{~b}$ & $20.4 \mathrm{~b}$ & $88 \mathrm{~b}$ & $65 \mathrm{~b}$ & $43 \mathrm{~b}$ & $33 \mathrm{~b}$ \\
\hline 0.250 & $58.2 \mathrm{~b}$ & $41.8 \mathrm{~b}$ & $29 a b$ & $22.7 \mathrm{~b}$ & $89 \mathrm{~b}$ & $68 \mathrm{~b}$ & $46 \mathrm{ab}$ & $35 \mathrm{~b}$ \\
\hline 0.500 & $70.0 \mathrm{a}$ & $54.2 \mathrm{a}$ & $35 \mathrm{a}$ & $31.4 \mathrm{a}$ & $105 \mathrm{a}$ & $84 \mathrm{a}$ & $52 \mathrm{a}$ & $47 \mathrm{a}$ \\
\hline \multicolumn{9}{|c|}{ Zinc $(\mathrm{ppm})$} \\
\hline Control & $9.4 \mathrm{c}$ & $7.3 \mathrm{c}$ & $5.7 \mathrm{~d}$ & $6.6 \mathrm{c}$ & $23.8 \mathrm{c}$ & $18.5 \mathrm{c}$ & $13 \mathrm{c}$ & $16 \mathrm{c}$ \\
\hline 0.125 & $22.8 \mathrm{~b}$ & $18.3 \mathrm{~b}$ & $9.9 \mathrm{c}$ & $11.3 \mathrm{~b}$ & $60.0 \mathrm{~b}$ & $46.6 \mathrm{~b}$ & $24 \mathrm{~b}$ & $29 \mathrm{~b}$ \\
\hline 0.250 & $37.2 \mathrm{a}$ & $29.7 \mathrm{a}$ & $14.8 \mathrm{~b}$ & $18.6 \mathrm{a}$ & $85.1 \mathrm{a}$ & $72.4 \mathrm{a}$ & $33 \mathrm{a}$ & $46 \mathrm{a}$ \\
\hline 0.500 & $40.3 \mathrm{a}$ & $33.4 \mathrm{a}$ & $18.0 \mathrm{a}$ & $21.2 \mathrm{a}$ & $87.0 \mathrm{a}$ & $75.8 \mathrm{a}$ & $30 \mathrm{a}$ & $42 \mathrm{a}$ \\
\hline \multicolumn{9}{|c|}{ Copper $(\mathbf{p p m})$} \\
\hline Control & $4.9 \mathrm{~d}$ & $3.8 \mathrm{~d}$ & $4.53 \mathrm{~d}$ & $3.41 \mathrm{c}$ & $11.7 \mathrm{~d}$ & $8.7 \mathrm{c}$ & $8.5 \mathrm{c}$ & $5.6 \mathrm{c}$ \\
\hline 0.125 & $11.4 \mathrm{c}$ & $8.9 \mathrm{c}$ & $6.42 \mathrm{c}$ & $3.93 \mathrm{~b}$ & $28.2 \mathrm{c}$ & $19.4 \mathrm{~b}$ & $14.6 \mathrm{~b}$ & $9.7 \mathrm{~b}$ \\
\hline 0.250 & $13.8 \mathrm{~b}$ & $10.5 \mathrm{~b}$ & $8.88 \mathrm{~b}$ & $6.30 \mathrm{a}$ & $29.5 \mathrm{~b}$ & $20.9 \mathrm{a}$ & $17.2 \mathrm{a}$ & $11.3 \mathrm{a}$ \\
\hline 0.500 & $14.7 \mathrm{a}$ & $11.4 \mathrm{a}$ & $9.45 \mathrm{a}$ & $6.76 \mathrm{a}$ & $30.9 \mathrm{a}$ & $21.1 \mathrm{a}$ & $16.1 \mathrm{a}$ & $10.8 \mathrm{a}$ \\
\hline
\end{tabular}


Busscher (1982), who stated that hydro-gels reduced fertilizer (NPK) leaching. Also, Finch-Savage and Cox (1982) found that hydro-gel increased $\mathrm{P}$ in the tissues of lettuce and onion, whereas Wang (1989) found that it increased nitrogen and potassium in plant tissues, too. Also, Geesing and Schmidhalter (2004) reported that grain $\mathrm{N}$ concentration increased in response to increasing the application rate of hydro-gels.

Trends observed for $\mathrm{N}, \mathrm{P}$, and $\mathrm{K}$ were, more or less, the same for micro-nutrients in barley plant tissues during its life span. It could be seen that the best application rate of soil conditioner was $0.25 \mathrm{Kg} / \mathrm{Ton}$ for bringing about the most suitable concentrations of $\mathrm{Fe}$, $\mathrm{Mn}, \mathrm{Zn}$, and $\mathrm{Cu}$ in barley plant tissue. The highest rate of of soil conditioner application of $0.50 \mathrm{Kg} /$ Ton could not incur a significant increase in these concentrations (Table 8). Again, it can be assured that the $0.25 \mathrm{Kg} / \mathrm{Ton}$ rate of application is the best for proliferating better moisture content in the soil and leads to the best germination performance, the most optimum levels of N, $\mathrm{P}, \mathrm{K}, \mathrm{Fe}, \mathrm{Mn}, \mathrm{Zn}$, and $\mathrm{Cu}$ uptake in barley plant tissues. This was supported by what Mortvedt et al. (1993) stated that polymers with soluble iron, copper, manganese, or zinc increased uptake efficiency of the applied micronutrient. Also, Mikkelsen (1995) revealed that hydrophilic polymer with soluble Mn fertilizers enhanced plant recovery and lowered Mn application rates.

These advantages were translated into the best 1000grain weight, number of spikes $/ \mathrm{m}^{2}$, and spikes weight $\left(\mathrm{g} / \mathrm{m}^{2}\right)$. This was also reflected in the form of grain and straw yields (g/pot). So, the best rate of soil conditioner application was obviously the $0.25 \mathrm{Kg} / \mathrm{Ton}$. The highest rate of $0.50 \mathrm{Kg} / \mathrm{Ton}$ could not bring any significant increases in both grain and straw yields (Table 9). In correspondence, Geesing and Schmidhalter (2004) reported that bio-mass and grain yields of plants increased with increasing polymer application rate.
In general, it can be concluded that the application of a hydrophillic soil conditioner is a helpful tool for the improvement of soil physical and chemical properties. This was reflected in improving plant growth traits. This application was evidently better than the control treatment. The application rate had a ceiling of $0.25 \mathrm{Kg}$ /Ton, because it was giving best results.

Table (10) shows that the nutrients' uptake of barley plants in both grain and straw was a steady function of the soil conditioner application rate. This can be easily seen in the table at the first glance. From another point of view, the insignificant differences, that were observed for some nutrient elements, whether macro- or micronutrient (Tables 7 and 8), can be considered a reflection of the attainment of the appropriate concentration of the respective elements that would allow plant cells function properly. So, the higher rate of soil conditioner application could not lead to a significantly higher concentration of the element. Plant selective absorption is, then, the key to such influence.

In conclusion, the higher rate of soil conditioner application, despite being significantly the best in effecting for the greatest uptake of nutrients, it could not translate that into a significantly greater grain and straw yields of barley plants. So, the best rate of the soil conditioner used in this study and the like ones is recommended to be the $0.25 \mathrm{Kg} / \mathrm{Ton}$. This rate is expected to be not only the most efficient, but also the most economic one and at the reach of the small farmers, as well.

With respect to plant uptake, it could successfully reflect the positive response of the plants to the conditions proliferated by each rate of application. The plants could significantly produce greater grain and straw yields in retard to increasing the conditioner rate of application. The resultant is, then, a remarkably steady increase in plants' uptake of both macro-nutrients (Table 10) and micro-nutrients (Table 11).

Table 9. Effects of soil conditioner level on barley and yield components in the two studied soils.

\begin{tabular}{ccccccc}
\hline \multirow{2}{*}{ Conditioner Kg/Ton } & \multicolumn{3}{c}{ Yield (g/pot.) } & Weight & \multicolumn{2}{c}{ Spikes/m $^{2}$} \\
\cline { 2 - 7 } & Bio & Grain & Straw & $\mathbf{1 0 0 0}(\mathbf{g})$ & W. Kg & No. \\
\hline \multicolumn{7}{c}{ Sand soils } \\
Control & $28.8 \mathrm{~d} *$ & $18.6 \mathrm{c}$ & $10.2 \mathrm{~d}$ & $17.1 \mathrm{c}$ & $0.16 \mathrm{c}$ & $101 \mathrm{~d}$ \\
0.125 & $79.8 \mathrm{c}$ & $56.8 \mathrm{~b}$ & $22.8 \mathrm{c}$ & $36.4 \mathrm{~b}$ & $0.37 \mathrm{~b}$ & $221 \mathrm{c}$ \\
0.250 & $111.0 \mathrm{~b}$ & $78.8 \mathrm{a}$ & $32.4 \mathrm{~b}$ & $46.8 \mathrm{a}$ & $0.60 \mathrm{a}$ & $282 \mathrm{~b}$ \\
0.500 & $122.6 \mathrm{a}$ & $86.0 \mathrm{a}$ & $36.8 \mathrm{a}$ & $49.4 \mathrm{a}$ & $0.64 \mathrm{a}$ & $333 \mathrm{a}$ \\
\hline \multicolumn{7}{c}{ Sandy loam soils } \\
\hline Control & $65.0 \mathrm{~d}$ & $43.6 \mathrm{c}$ & $21.4 \mathrm{c}$ & $29.9 \mathrm{c}$ & $0.54 \mathrm{c}$ & $164 \mathrm{c}$ \\
0.125 & $102.2 \mathrm{c}$ & $67.4 \mathrm{~b}$ & $35.0 \mathrm{~b}$ & $51.5 \mathrm{~b}$ & $0.97 \mathrm{~b}$ & $297 \mathrm{a}$ \\
0.250 & $114.4 \mathrm{~b}$ & $72.0 \mathrm{~b}$ & $42.6 \mathrm{a}$ & $54.4 \mathrm{a}$ & $1.29 \mathrm{a}$ & $301 \mathrm{a}$ \\
0.500 & $161.8 \mathrm{a}$ & $117.0 \mathrm{a}$ & $44.8 \mathrm{a}$ & $55.7 \mathrm{a}$ & $1.40 \mathrm{a}$ & $301 \mathrm{a}$ \\
\hline
\end{tabular}

* In each column (box) for each soil, every two values sharing an alphabet are not significantly different at 5\% level of significance, Bio (Biological), W.Kg (Weight spikes by Kg), No (Number of spikes) 
HUSSEIN KH. AHMED , HASSAN A. FAWY : EFFECT OF TEZLIEN-N7000 SOIL CONDITIONER ON PHYSICAL AND ...

Table 10. Effect of soil conditioner level on barley plants' uptake of $N, P$, and $K$ (mg/pot) in grain and straw in the two studied soils.

\begin{tabular}{|c|c|c|c|c|c|c|}
\hline \multirow{2}{*}{ Conditioner $\mathrm{Kg} / \mathrm{Ton}$} & \multicolumn{3}{|c|}{ Grain } & \multicolumn{3}{|c|}{ Straw } \\
\hline & $\mathbf{N}$ & $\mathbf{P}$ & $\mathbf{K}$ & $\mathbf{N}$ & $\mathbf{P}$ & $\mathbf{K}$ \\
\hline \multicolumn{7}{|c|}{ Sand soils } \\
\hline Control & $43 \mathrm{~d}^{*}$ & $7 \mathrm{~d}$ & $65 \mathrm{~d}$ & $73 \mathrm{~d}$ & $11 \mathrm{~d}$ & $12 \mathrm{~d}$ \\
\hline 0.125 & $267 \mathrm{c}$ & $45 c$ & $511 \mathrm{c}$ & $296 c$ & $52 \mathrm{c}$ & $59 \mathrm{c}$ \\
\hline 0.250 & $457 \mathrm{~b}$ & $102 \mathrm{~b}$ & $914 b$ & $544 \mathrm{~b}$ & $94 \mathrm{~b}$ & $113 \mathrm{~b}$ \\
\hline 0.500 & $550 \mathrm{a}$ & $120 \mathrm{a}$ & $1049 \mathrm{a}$ & $670 \mathrm{a}$ & $114 \mathrm{a}$ & $140 \mathrm{a}$ \\
\hline \multicolumn{7}{|c|}{ Sandy loam soils } \\
\hline Control & $196 \mathrm{~d}$ & $35 \mathrm{~d}$ & $244 \mathrm{~d}$ & $289 \mathrm{~d}$ & $39 \mathrm{~d}$ & $47 \mathrm{~d}$ \\
\hline 0.125 & $404 \mathrm{c}$ & $135 \mathrm{c}$ & $1227 \mathrm{c}$ & $609 c$ & $137 \mathrm{c}$ & $133 \mathrm{c}$ \\
\hline 0.250 & $619 \mathrm{~b}$ & $166 \mathrm{~b}$ & $2117 b$ & $886 \mathrm{~b}$ & $196 \mathrm{~b}$ & $281 \mathrm{~b}$ \\
\hline 0.500 & $1217 \mathrm{a}$ & $304 \mathrm{a}$ & $3615 \mathrm{a}$ & $1219 \mathrm{a}$ & $215 \mathrm{a}$ & $305 \mathrm{a}$ \\
\hline
\end{tabular}

* In each column (box) for each soil, every two values sharing an alphabet are not significantly different at $5 \%$ level of significance.

Table 11. Effect of soil conditioner level on barley plants' uptake of $\mathrm{Fe}, \mathrm{Mn}, \mathrm{Zn}$, and $\mathrm{Cu}$ in grain and straw in the two studied soils.

\begin{tabular}{|c|c|c|c|c|}
\hline \multirow{3}{*}{ Conditioner $\mathrm{Kg} / \mathrm{Ton}$} & \multicolumn{4}{|c|}{ Micronutrients' uptake (mg/pot) } \\
\hline & \multicolumn{2}{|c|}{ Sand soil } & \multicolumn{2}{|c|}{ Sandy loam soil } \\
\hline & Grain & Straw & Grain & Straw \\
\hline \multicolumn{5}{|c|}{ Iron } \\
\hline Control & $0.84 \mathrm{~d}^{*}$ & $0.41 \mathrm{~d}$ & $3.18 \mathrm{~d}$ & $1.46 \mathrm{~d}$ \\
\hline 0.125 & $4.60 \mathrm{c}$ & $1.66 \mathrm{c}$ & $9.71 \mathrm{c}$ & $4.80 \mathrm{c}$ \\
\hline 0.250 & $8.20 \mathrm{~b}$ & $3.21 \mathrm{~b}$ & $13.03 \mathrm{~b}$ & $7.24 \mathrm{~b}$ \\
\hline 0.500 & $10.58 \mathrm{a}$ & $4.31 \mathrm{a}$ & $22.82 \mathrm{a}$ & $8.15 \mathrm{a}$ \\
\hline \multicolumn{5}{|c|}{ Manganese } \\
\hline Control & $0.28 \mathrm{~d}$ & $0.13 \mathrm{~d}$ & $1.09 \mathrm{~d}$ & $0.41 \mathrm{~d}$ \\
\hline 0.125 & $1.42 \mathrm{c}$ & $0.47 \mathrm{c}$ & $2.90 \mathrm{c}$ & $1.16 \mathrm{c}$ \\
\hline 0.250 & $2.29 \mathrm{~b}$ & $0.74 \mathrm{~b}$ & $3.31 \mathrm{~b}$ & $1.49 \mathrm{~b}$ \\
\hline 0.500 & $3.01 \mathrm{a}$ & $1.16 \mathrm{a}$ & $6.08 \mathrm{a}$ & $2.11 \mathrm{a}$ \\
\hline \multicolumn{5}{|c|}{ Zinc } \\
\hline Control & $0.11 \mathrm{~d}$ & $0.07 \mathrm{~d}$ & $0.57 \mathrm{~d}$ & $0.34 \mathrm{~d}$ \\
\hline 0.125 & $0.56 \mathrm{c}$ & $0.26 \mathrm{c}$ & $1.62 \mathrm{c}$ & $1.02 \mathrm{c}$ \\
\hline 0.250 & $1.17 \mathrm{~b}$ & $0.60 \mathrm{~b}$ & $2.38 \mathrm{~b}$ & $1.96 \mathrm{~b}$ \\
\hline 0.500 & $1.55 \mathrm{a}$ & $0.78 \mathrm{a}$ & $3.51 \mathrm{a}$ & $1.88 \mathrm{a}$ \\
\hline \multicolumn{5}{|c|}{ Copper } \\
\hline Control & $0.08 \mathrm{~d}$ & $0.03 \mathrm{~d}$ & $0.37 \mathrm{~d}$ & $0.12 \mathrm{~d}$ \\
\hline 0.125 & $0.36 \mathrm{c}$ & $0.09 \mathrm{c}$ & $0.98 \mathrm{c}$ & $0.34 \mathrm{c}$ \\
\hline 0.250 & $0.70 \mathrm{~b}$ & $0.20 \mathrm{~b}$ & $1.24 \mathrm{~b}$ & $0.48 \mathrm{~b}$ \\
\hline 0.500 & $0.81 \mathrm{a}$ & $0.25 \mathrm{a}$ & $1.88 \mathrm{a}$ & $0.48 \mathrm{a}$ \\
\hline
\end{tabular}

* In each column (box) for each soil, every two values sharing an alphabet are not significantly different at $5 \%$ level of significance.

\section{REFERENCES}

Abraham, J. and V.N. Rajasekharan Pillai. (1995). N, Nmethylene bisacrylamide-crosslinked polyacrylamide for controlled release urea fertilizer formulations. Communications in Soil Science and Plant Analysis 26(19\&20): 3231-3241.

Al-Harbi, A.R., A.M. Al-Omran, A.A. Shalalay, and M.I. Choudhary. (1999). Efficacy of a hydrophilic polymer declines with time in greenhouse experiments. HortScience 34(2): 223-224.

Black, C.A.; D.D. Evans; J.L. White; L.E. Ensminger and F.E. Clark (1982). Methods of Soil Analysis. Amer. Soc. Agron. Inc., Madison, Wisconsin, U.S.A.
Choudhary MI Shalaby AA \& Al Omran AM 1995. Water holding capacity and evaporation of calcareous soils as affected by four synthetic polymers.

Duncan, D.B. (1955). Multiple range and multiple F-test. Biometrics 11: 1-24.

El Sayed, H., R.C. Kirkwood, and N.B. Graham. 1991. The effects of hydrogel polymer on the growth of certain horticultural crops under saline conditions. Journal of Experimental Botany 42(240): 891-899.

Finch-Savage, W.E. and C.J. Cox (1982). Effects of adding plant nutrients to the gel carrier used for fluid drilling germinating lettuce and onion seeds. Annuals of Applied Biology 102: 213-217. 
Flannery, R.L. and W.J. Busscher (1982). Use of a synthetic polymer in potting soils to improve water holding capacity. Communications in Soil Science and Plant Analysis 13 (2) : 103 - 111.

Geesing, D. and U. Schmidhalter (2004). Influence of sodium polyacrylate on the water-holding capacity of three different soils and effects on growth of wheat Soil Use and Management 20, 207-209.

Gohar, A.A.A.I. (1954). The influence of exchangeable cations on soil properties of Egyptian soils. M.Sc. Thesis, Fac. of Agric., Cairo Univ., Ewgypt.

Gomez, K.A. and A.A. Gomez (1984). Statistical procedures for agricultural Res. $2^{\mathrm{n}}$ ed. Wiley, New York.

Klute, A. (1986). Methods of Soil Analysis. Part 1, $2^{\text {nd }}$ es. Agronomy 9.

Lindsay, W.L. and W.A. Norvell (1978). Development of DTPA soil test for zinc, iron, manganese and copper. Soil Sci. Soc. Am. Proc. 42: 421-428.

Micich,T.J and Linfield,W.M.(1986) anionic surfactant amides as sol wetting agent.JAOCS.63.10,1385-1391.

Mikkelsen, R. L. (1995). using hydrophilic polymers to improve uptake of manganese fertilizers by soybeans. Fertil-res v.41, p.87-92.

Mortvedt, John J.; Mikkelsen, Robert L.;(1993) Micronutrient delivery systems using hydrophilic polyacrylamides United States Patent 5221313, Tennessee Valley Authority (Muscle Shoals, AL)

Olsen, S.R.; C.J. Cole; F.S. Watanabe and L.A. Dean (1954). Estimation of available phosphorus $\mathrm{n}$ soils by extraction with sodium bicarbonate. Circ. No. 939, USDA. U.S. Government Printing Office, Washington, DC.

Onken, A.B. and H.D. Sunderman (1977). Colorimetric determinations of exchangeable ammonium, urea, nitrate, and nitrite in a single soil extract. Agron. J. 69: 49-53.

Page, A.L.; R.H. Miller and D.R. Keeney (1982). Methods of soil analysis. Part 2: Chemical and microbiological properties. Second Edition. Agron. J. 9: 2.
Parkinson, J.A. and S.E. Allen (1975). A wet oxidation procedure suitable for the determination of nitrogen and mineral nutrients in biological material. Commun. Soil Sci. Plant Anal., 6: 1-11.

Polyakova, Y.Y. (1976). Polymers - soil conditioners and nitrogen fertilizers. Soviet Soil Science 8(4): 443-446.

Richards, L.A. (1954). Diagnosis and Improvement of Saline and Alkali Soils. U.S. Dept. Agric. Handbook, No. 60. U.S. Govt. Print. Off., Washington, D.C. USA

Sivapalan, S. (2004). Effect of Polymer on Soil Water Holding Capacity and Plant Water Use Efficiency. Charles Sturt University, Wagga, NSW, Proceedings of the Australian Agronomy Conference, Australian Society of Agronomy.

Trout, T. J.; Sojka, R. E.; Lentz, R. D. (1995). Polyacrylamide effect on furrow erosion and infiltration. Trans-ASAE v.38, p.761-766.

Wallace, A. and G.A. Wallace (1986b). Effects of very low rates of synthetic soil conditioners on soils. Soil Sci. 141(5): 324 - 327

Wallace, A. and G.A. Wallace (1990). Effects of very low rates of synthetic soil conditioners on soils. Soil Science 141 (5): 324 - 327.

Wang, Y. (1989). Medium and hydrogel effect on production and wilting of tropical ornamental plants. HortScience 24(6): 941-944.

Wettstein, D. (1957). Chlorophyll letal und der sub micoscopische. Formonech Sell-derplastiden, Exptl. Cell. Res. 12: 427-433.

Wolf, B. (1982). A comprehensive system of leaf analysis and its use for diagnosing crop nutrient status. Commun. Soil Sci. Plant Anal., 13: 1035-1058.

Woodhouse, J.M. and M.S. Johnson (1991). The effect of gelforming polymers on seed germination and establishment. Journal of Arid Environments 20: 375-380.

Zhang, X.C. and W.P. Miller. (1996). Polyacrylamide effect on infiltration and erosion in furrows. Soil Science Society of America Journal 60: 866-872. 


\section{الملخص العربي}

تأثير محسن التربة (تيزليين-ن7000 ) على الحواص الكيميائية والطبيعية للتربة ونمو نبات الشعير فى أرضيين

$$
\text { حسين خالد أحمد 1 و حسنلفتين من الاراضى المصرية عبد العاطي فاوي } 2
$$

أجريت بحربة أصص في صوبة نباتيـة ، وكان المدف مـن هـذا وقد خلط محسن التربة نيزلين-ن 7000 جيداً بالتربة في كل إصيص

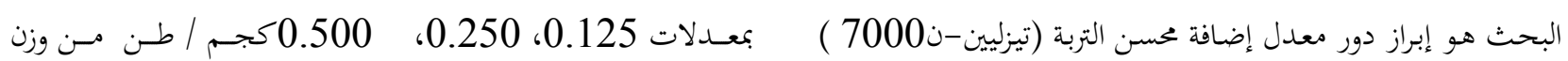

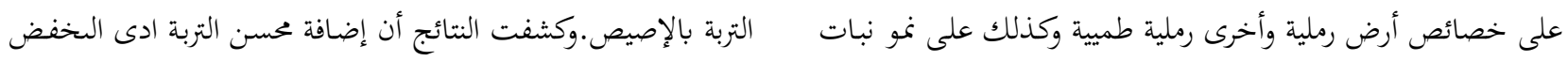

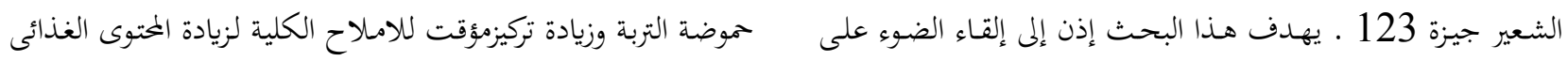

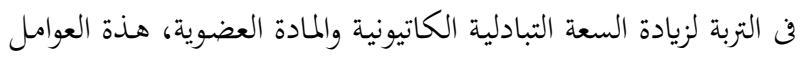

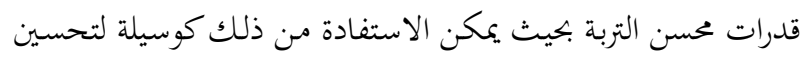
انعكست بالايجابية على انتاجية الشعير والمستوى العنصـرى بهـا.

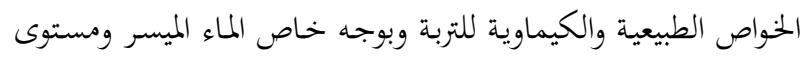

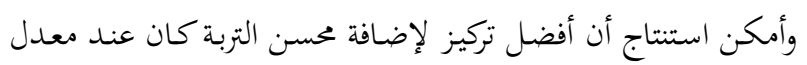

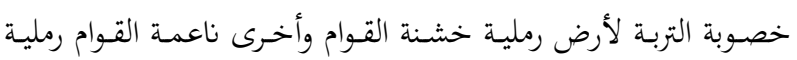

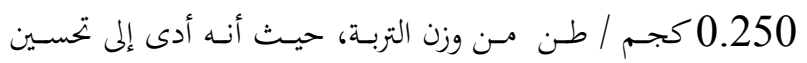

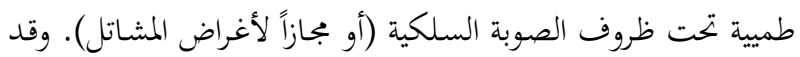

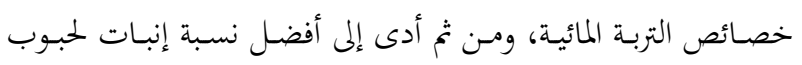

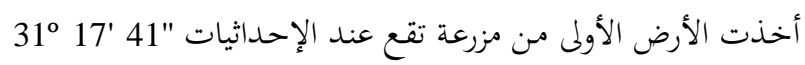

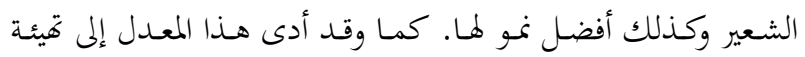

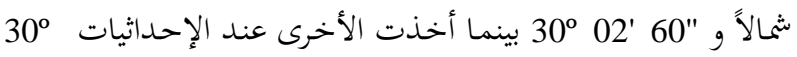

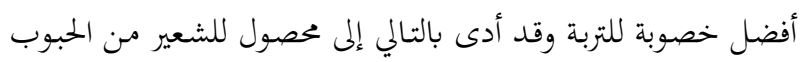

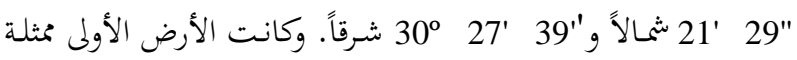
والقش.وان استخدام محسن التربة كان اكثر كفاءة فن الاراضى الرملية

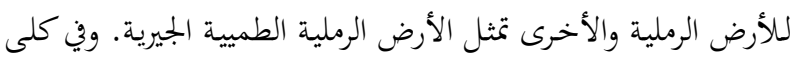
عن الاراضى الرملية الطميية.

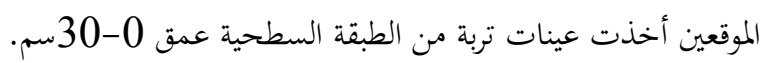

